\title{
EXTRA-JUDICIAL WRITING: THE ALBERTA LAW QUARTERLY AND THE ALBERTA LAW REVIEW IN PARTICULAR, AND TEXTS AND REVIEWS IN GENERAL
}

\author{
W. F. BOWKER*
}

This is the text of Dean Bowker's address to guests and members of the Alberta Law Review delivered on the occasion of the Review's 25th Anniversary banquet February 7, 1980. In order to preserve the original tone and style of the address, only minor editorial changes have. been made.

\section{INTRODUCTION}

Thanks indeed. The first thing that comes to my mind is whether I can be heard at the back of the room. At one time, the complaint was not that I could not be heard at the back of the room, but that people in the other room could hear me too and did not particularly appreciate it. But with the passage of time, I think that perhaps I had better rely on the microphone.

Now, Mr. Chairman, as Trevor Anderson ${ }^{1}$ was making his most kind remarks, this crossed my mind. Three or four years ago when Mr. Justice Stevenson was president of the Sir Winston Churchill Society, Lord Shawcross was invited to speak and Mr. Justice Stevenson had the perspicacity to bring Trevor back from Winnipeg to introduce him. Some of the local dinosaurs said, "What are they bringing in an import for?". Well, Trevor gave the best introduction of a Churchill speaker that was ever given. I only mention that for this reason: his introduction to Lord Shawcross, I think, took 14 minutes. The one tonight, although I didn't clock him, you know, I think took 16 minutes. I won't say anything about his sense of proportion, except that it is rather flattering to myself.

What I want to do in my remarks tonight is to deal with two aspects of the same subject. The first is legal writing here, through the old Quarterly and now the Review, and the second is the influence of extra-judicial legal writing on the shaping of the law.

Dr. MacIntyre ${ }^{2}$ has been mentioned several times tonight in Trevor Anderson's remarks. He came here in 1930, and we were bewildered by Dr. MacIntyre after having had Dean Weir, ${ }^{3}$ a master of the Socratic method, and also Mr. Steer, ${ }^{4}$ who laid everything out cold. MacIntyre was full of doubts. I am going to mention two little incidents connected with Dr. MacIntyre because he had a great influence on all of us.

I remember when the decision was made to commission pictures by Grandmaison of Mr. Steer and L. Y. Cairns. ${ }^{5}$ We went down to Calgary and Dick Burns, ${ }^{6}$ whom I am most delighted to see here tonight, was our Calgary liaison. We had a lovely gathering in his home. One

* Professor Emeritus and former Dean of the Faculty of Law, University of Alberta.

1. Of the Faculty of Law, University of Manitoba. Mr. Anderson delivered the Introduction to Dr. Bowker's address on this occasion.

2. Dr. Malcolm M. MacIntyre, Dean of the Faculty of Law, University of Alberta, 1942-1944. See also W. F. Bowker, "Malcolm Murray MacIntyre, 1904-1964" (1964) 3 Alta. L. Rev. 161.

3. Dean John Weir, the first Dean of the Faculty of Law, University of Alberta (from 1921 to 1942).

4. G. H. Steer, Q.C., Acting Dean from 1944 to 1947.

5. The late Judge L. Y. Cairns, who was for many years a part-time lecturer in the Faculties of Law and Commerce.

6. R. J. Burns, Q.C., of the firm Macleod Dixon in Calgary. 
troublemaker there said, "Well, it's all right to have a picture of L. Y. Cairns, but I never liked Mr. Steer, and we've got to have MacIntyre there". So there was a great debate about the respective virtues of $\mathrm{Mr}$. Steer and MacIntyre, and we wound up commissioning a picture of MacIntyre too. You can see all three of them in the lobby up on the fourth floor [of the Law Centre, University of Alberta]. If it had not been for Dick's help and the advocacy of this other chap who wanted MacIntyre there, we would not have had his picture. He would not let Grandmaison do his picture. Somebody out at the Coast did it. I was not particularly happy with the picture at the time, but now I am glad that we have it there.

There is one other comment I want to make about MacIntyre, though I don't think I can do justice to it. I had a chat with Mr. Justice Morrow years ago ${ }^{7}$-and I am pleased that Mr. Justice Morrow is here tonight. I remember, when I expressed some misgivings or deprecations of MacIntyre, Mr. Justice Morrow said, "Well, when he came along I saw for the first time", (and I don't think I can do justice to the way he put it), "that the answers aren't all pat, they don't come out like a syllogism. I saw the light when MacIntyre taught us to see that there are two sides to every problem and we want to try to figure out the solution in the best social way". Of course, MacIntyre had been a student of Dean Pound, and I think that is what Bill Morrow was trying to convey. I think Bill's remark made me appreciate MacIntyre more than I ever had before. He went out to the Law Faculty at U.B.C. later, and when you talked to any student from that law school, you knew that they just thought the world of him. It is true that he spent a month on the Loach ${ }^{8}$ case and he would bring in the Loach case whatever was the topic-he had no sense of timing, and no idea of any framework-but I think certainly Mr. Burns and Mr. Justice Morrow and Mr. Corbett, ${ }^{9}$ and others here tonight who were students of his, like myself, feel greatly indebted to MacIntyre.

\section{LEGAL WRITING IN ALBERTA}

Now, Dr. MacIntyre was the man who conceived the idea of the Law Quarterly. Dean Weir wasn't enthusiastic, but MacIntyre instituted it. I took a quick look through some of the five volumes and I will say this: they were nearly all student articles and they are a good cross-section of the legal issues that we had in this Province at that time. We were in the midst of the Depression. There was all manner of litigation about the constitutionality of early Social Credit legislation, and you can find case notes and comments on those very important and sometimes bitter issues that we faced in Canada in the mid-thirties. I think there are some hidden nuggets there that are very valuable as part of our legal history.

Now there was one thing I noticed tonight. I never remembered it before in connection with the Quarterly and I want to tell you about it now. As soon as it was established, MacIntyre went to the Board of Governors and invited them to make an award for the best student articles in the Law Quarterly. MacIntyre got $\$ 50$ from the Board of

7. The Honourable Mr. Justice William G. Morrow of the Alberta Court of Appeal. His untimely death occurred on August 13,1980, as this article was going to press.

8. Loach v. B.C. Elec. Ry. Co. (1915) 23 D.L.R. 4 (P.C.), affg. (1914) 16 D.L.R. 245 (B.C.C.A.). Dr. MiacIntyre's classic article on this case is "The Rationale of Last Clear Chance" (1940) 53 Harv. L. Rev. 1225, 18 Can. Bar Rev. 665.

9. John H. Corbett, Q.C., of Corbett, Benkendorf, Hodgson \& Lachambre in Edmonton. 
Governors. The awards that I saw had to do with the year 1935 and the year 1936. The $\$ 50$ was split twelve different ways. In the first year I forget who won the top prize of $\$ 10$; but I can say this, and maybe $\mathrm{Mr}$. Burns will correct me if I am wrong: in the second year, 1936, he, as a recent graduate, got the top prize of $\$ 12$ for his student effort, and I am sure it set him up in practice and he is still in practice. As to other names there, I think McDermid ${ }^{10}$ came in at $\$ 8.00$, Riley ${ }^{11}$ came in at $\$ 9.00$ or $\$ 6.00$, and there are some names that you would not recognize so I won't bother naming them. I see Peter Costigan here tonight. I hate to say this, Peter, but your father ${ }^{12}$ came in at $\$ 3.00$. This all appears in the Alberta Law Quarterly. ${ }^{13}$ I was touched by seeing it because nearly every one of those names turned out to be one of distinction in the years following. We can make fun about that pittance, but it had as much significance then as a much larger award would have today.

There was one type of article which they ran, and I applaud thisarticles on English judges and lawyers; tiny little ones, but they are still worth preserving and I am glad we have them. Then there was another kind of article and I can remember three of them, but there might have been more. They had to do with practical matters. They included forms and precedents, and the first one was by L. Y. Cairns and Ermest Wilson ${ }^{14}$ on foreclosure practice in Alberta. ${ }^{15}$ Well, all I can say is this: I did a lot of that work in that period and the article by Cairns was always at my elbow. I learned more about the Rules of Court of Alberta and foreclosure practice from that article than from any other single source.

The second one was on originating notices of motion-that's really an exciting topic, I know-by my classmate Bill Parlee..$^{16}$ I am sure that there was a judgment that cited Parlee's note, and it is the only piece in the Law Quarterly which was ever cited, to my knowledge. I spent a half-day trying to find it and I wasn't able to find it, but I think you could take my word for it that Parlee's article on originating notices of motion was, in fact, cited.

Now I'm going to come to the third article. I do this with some diffidence because, Mr. Chairman, it was my own. ${ }^{17}$ It was on divorce practice in Alberta. Now, those knowledgeable about divorce like Leonard Pollock ${ }^{18}$ might understandably ask, "What does this chap know about divorce practice?". Well, the answer is, not very much; but I wanted to learn something about it, so I went to the Committee that we had during the Depression called The Needy Litigants Committee which gave permits to bring actions without any fees. It was a good way for young people to get some experience, and I had several of these. I went to them and said, "Will you give me a divorce case?", and they said, "We don't give a Needy Litigants certificate for divorce cases. These are a luxury

10. The Honourable Mr. Justice N. D. McDermid of the Alberta Court of Appeal.

11. The late Mr. Justice Harold Riley of the Trial Division, Supreme Court of Alberta.

12. T. J. Costigan, Q.C., of Blairmore, Alberta.

13. See "Special Awards" (1935) 1 Alta. L.Q. 168 and (1936) 2 Alta. L.Q. 29.

14. The late Mr. Justice E. B. Wilson of the Trial Division, Supreme Court of Alberta. His son William E. Wilson, Q.C., was at the banquet.

15. L. Y. Cairns, "Foreclosure of Land Mortgages in Alberta by Way of Court Procedure" (1938) 2 Alta. L.Q. 193.

16. W. O. Parlee, "Originating Notice of Motion" (1940) 3 Alta. L.Q. 223. W. O. Parlee, Q.C. is the head of Parlee, Irving, Henning, Mustard \& Rodney in Edmonton.

17. W. F. Bowker, "Procedure in Divorce Actions in Alberta" (1938) 3 Alta. L.Q. 51.

18. Professor L. J. Pollock, Q.C., of the Faculty of Law, The University of Alberta. 
and they can pay it on their own". But they made an exception for me and they gave me a case. My client was the most scurvy character who ever asked for divorce in Alberta. But I did what I could to learn something about the practice and when Jim Wallbridge, one of the boys from the Law Quarterly, came to me a short time later (this was around 1937) and said, "Will you write something for the Quarterly?", I thought, well, I'll write a piece on divorce practice in Alberta. But there was no Kent Power ${ }^{19}$ in those days. I don't want to laud my own piece but several solicitors, particularly in the country, did say they found those precedents useful, and I don't think any judge ever said they were in error.

That little piece of mine once stood me in good stead and I'd like to tell you about it. In 1962, I received an anguished phone call from a Vancouver solicitor. He said, "Will you come out to Vancouver to give expert evidence on the law of Alberta on this point? If one of the spouses, after a decree nisi but before the decree absolute goes through a form of marriage, is that marriage valid?". Now you might say, Mr. Chairman, "why would they ask that question?". We all know it isn't valid. But remember, B.C. took the law of England as of 1858 and the requirement of a decree nisi wasn't in the 1857 Matrimonial Causes Act. It was in an amendment that came into effect between 1858 and 1870. We all know that we took the law as of 1870 , and Board v. Board ${ }^{20}$ said that our judges had jurisdiction in divorce. I said I would go, and my wife typed out a little memo that night, and I appeared before Mr. Justice Ruttan the next day.

Now, I have a bit of a quiff. I don't like the word expert. Everybody who ever proclaims anything on any subject is reported in the newspapers as an expert, and I think it's a word that has become cheapened. But technically I had to be qualified as an expert. And I should perhaps say this, that when that lawyer first phoned me and put this problem to me, I said, "Whichever side you're on, that marriage is invalid and I don't care what you want me to say, that's all I'm going to say". Well, it turned out that was what he wanted me to say. So I went out and when I was being qualified I had to show my credentials and I only had two. The first one was that I had taught Domestic Relations one year; but the real clincher was that I had written an article on divorce practice in Alberta in the Alberta Law Quarterly. So there was no question about my qualifications.

If you want to read that case, it is Rogers v. Imperial Life. ${ }^{21}$ It went to the Court of Appeal. It involved an insurance policy and the marriages came into it this way: the lady was an adventuress and she married Husband No. 1 in Alberta, then after the decree nisi purported to marry Husband No. 2, then later married Rogers. If the second marriage was good, then she was not married to Rogers; but the fact was, the second marriage wasn't effective because it took place between the nisi and the absolute. Rogers was her husband, and she got the insurance. That was a bit of indirect influence of the Alberta Law Quarterly.

Now I want to move to the next era. I won't talk about the demise of the Alberta Law Quarterly because I had to preside over its funeral when

19. This reference is to the author of Power on Divorce and Other Matrimonial Causes, who also edited Power's Western Practice Digest and the Western Weekly Reports.

20. [1919] A.C. 956.

21. Re Rogers (Deceased) (1963) $4 \overline{2}$ W.W.R. 200 (B.C.C.A.), affg. (1962) 40 W.W.R. 317 (B.C.S.C.). 
I came in the fall of 1945. Mr. Justice Stevenson and Dr. Alex Smith have written pieces on the subject. You can read about it in the 25th Anniversary Issue of the Alberta Law Review. ${ }^{22}$ The Quarterly died at the end of the war, and when I came in September, 1945, all I had was an office full of unmailed issues of the last part of Volume 5 of the Alberta Law Quarterly. I'm not going to labour that.

The next phase I want to describe is this. Trevor Anderson was kind enough to refer to my effort to do something in legal writing. I might add that when John Willis wrote his history of the Dalhousie Law School ${ }^{23}$ and described their course in legal writing under George Nicholls in the late 50's and 60's, he did make this concession: he said, "Well, there had been a course in Alberta before ours. It was one in legal writing of a sort." 24 Now, you get the innuendo there. But I want to say this: beginning in 1950, going through 1958 (and by this time the Review was started), we did have, from students in this law school, nine articles in the Canadian Bar Review. ${ }^{25}$ No other.law school ever came within a mile of that.

I want to say something about these articles, or rather, case notes. They came from the course that Trevor mentioned. There were nine of them, but one was a double article, so there were ten authors. Two of those men have died, Bill Stainton of Edmonton and Bob Neve of Calgary. Three of them are practitioners: Miles Patterson and Gordon Brown of Calgary, and James Enright of Edmonton (who is here tonight). Patterson's case note I shall mention in a moment. Gordon Brown's article predicted the result in the Berkheiser case, ${ }^{26}$ on the nature of an oil and gas lease. Gordon's comment was on a Saskatchewan case, $R e$ Sykes. ${ }^{27}$ He said quite correctly that it was dead wrong. I was always very proud of Gordon's article.

The case note by Jimmy Enright was on Beaver v. The King, ${ }^{28}$ on the onus in narcotics cases. I'll say this to you: there may be some here tonight who think that students do not have any scholarship. I point out, and Jimmy may remember this, that his article is the only writing I know of in Canada that cites Lon Fuller's "Speluncean Explorers";29 and if you don't know what Lon Fuller's "Speluncean Explorers" is, I won't take the time to say.

Most of those articles were on evidence. There was one by Jim Woods, who is now a Provincial Court judge. There were two by Queen's Bench

22. Alberta Law Review Twenty.Fifth Anniversary Issue (February 1980), at 38, 45.

23. J. Willis, A History of Dalhousie Law School (1979, University of Toronto Press). See also W. F. Bowker, "Legal Writing at the University of Alberta" (1959) 13 U. of T.L.J. 85

24. Id. at 187. The exact words are "The Alberta Law School had had one of a kind since 1944".

25. The nine articles appearing in the Canadian Bar Review are: M. H. Patterson and D. C.

Prowse, "Torrens System-Wilkie v. Jellett" (1950) 28 Can. Bar Rev. 456; J. S. Woods, "Evidence-Tests for Alcoholic Intoxication" (1951) 29 Can. Bar Rev. 521; W. J. Stainton, "Criminal Law-Receiving Stolen Goods" (1951) 29 Can. Bar Rev. 885; W. G. N. Egbert, "Divorce-Standard of Proof of Adultery" (1952) 30 Can. Bar Rev. 753; R. R. Neve, "Homicide-Corpus Delicti-Circumstantial Evidence" (1955) 33 Can. Bar Rev. 603; W. G. Brown, "Oil and Gas Lease-Sale of Minerals" (1956) 34 Can. Bar Rev. 730; I. L. Head, "Real Property-Torrens System of Land Registration in Saskatchewan" (1956) 34 Can. Bar Rev. 736; W. A. Stevenson, "Bailment-Owner's Risk Clause" (1957) 35 Can. Bar Rev. 1100; J. E. Enright, "Opium and Narcotic Drug-Possession" (1958) 36 Can. Bar Rev. 562.

26. Berkheiser v. Berkheiser [1957] S.C.R. 387.

27. Re Sykes Estate (1955) 16 W.W.R. 459 (Sask. C.A.), affg. 16 W.W.R. 172 (Sask. Q.B.). Revd. [1957] S.C.R. 387.

28. [1957] S.C.R. 531; 26 C.R. 193; 118 C.C.C. 129 (S.C.C.).

29. L. Fuller, "The Case of the Speluncean Explorers" (1949) 62 Harv. L. Rev. 616. 
judges. One was by Mr. Justice Stevenson on cars stored at owner's risk, which was an important issue for many years, and one was by $\mathrm{Mr}$. Justice William Egbert. Of the present Court of Appeal, there was a piece by Clifton Prowse that he wrote with Miles Patterson. It was a very learned case note on a judgment of the Saskatchewan Court of Appeal in a case called Clark v. Barrick. ${ }^{30}$ It dealt with the effect of a caveat, and it was the best piece that has ever been written on the effect of a caveat. But they found the frustration many of us do: they wrote this learned article, waited to see what the Supreme Court would do, and the Supreme Court of Canada finally said, "We don't have to deal with the caveat because the acceptance was too late. The offeree waited too long." So we never had the satisfaction of knowing whether the Supreme Court agreed with this article.

The last individual in this group is Ivan Head. If you don't know who Ivan Head is, I'm not going to take time to tell you. His article was on Guay v. The Sun Publishing Company ${ }^{31}$ and he wrote that as a student. Of course, he and Mr. Justice Laycraft wrote a later article ${ }^{32}$ and he has written a great deal more, but the first piece he ever wrote was the case note on Guay. Whether or not I have any right to be proud of those articles, I am.

Then the Review came along and I remember one article that appeared during the transition, and I see Dick Dunlop ${ }^{33}$ here tonight. Maybe he can correct me if I'm wrong. In the period I speak of, George Nicholls was the editor of the Canadian Bar Review; and if there ever was an exacting editor, it was George Nicholls. I sent him a couple of pieces, including the ones Trevor Anderson mentioned to you, and I got the blue pencil page after page. None of these student articles got the treatment I did. That shows something about the quality of manuscripts that were submitted to Mr. Nicholls. As I recall, we sent Dick Dunlop's manuscript down. It had to do with an oil and gas development contract. The non-operator alleged that the operator was in a fiduciary relationship to the non-operator and that the operator had been in breach of its fiduciary duties. The Supreme Court of Canada said there was no breach. Dunlop's case note was a scholarly criticism of the majority judgment. It ultimately appeared in the Alberta Law Review. ${ }^{34}$ I think it was during the transition period. And I was proud of that article-I am glad it came out in our Review rather than in the Canadian Bar Review, but I recall that Nicholls made constructive comments on the case note and that he said, "I want to encourage young people". If you got past George Nicholls, you were pretty good.

There was one other article. It started off in the same course (Legal Writing) as an article on the law dealing with Hutterites in Alberta. It was by a student by the name of Douglas Sanders, who has become a very outstanding civil liberties lawyer in British Columbia. I thought it would be in the Alberta Law Review, but he parlayed it up until it

30. [1951] S.C.R. 177, revg. [1949] 2 W.W.R. 1009 (Sask. C.A.).

31. [1953] 2 S.C.R. 216, affg. 5 W.W.R. (N.S.) 97, revg. 4 W.W.R. (N.S.) 549.

32. I. L. Head and J. H. Laycraft, "Theories of Ownership of Oil and Gas" (1953) 31 Can. Bar Rev. 382.

33. Professor Richard Dunlop of the Faculty of Law, The University of Alberta.

34. R. Dunlop, "Oil and Gas Development Contract-Interpretation" (1969) 1 Alta. L. Rev. 466, a comment on Midcon Oil \& Gas Limited v. New British Dominion Oil Co. [1958] S.C.R. 314. 
appeared in the Canadian Law Review..$^{35}$ You can find Sanders' article there, but it had its origin in our course on legal writing.

\section{THE INFLUENCE OF LEGAL WRITING GENERALLY}

I want to move now to the second part of my talk, which has to do with the influence of writing by scholars on the development of the law. Now, I am no authority on Roman law but this statement seems to be accepted: that in Roman law, and in the modern codes that are based on the Roman law, including Quebec's Civil Code, the writings of scholars have much more weight than the judgment of a court. The writings of scholars are called doctrine and the writings of judges are called jurisprudence, and it is doctrine that has the weight. If you read a case from Quebec, even today, dealing with the Code, it is going to pay much more attention to these writers with names like Planiol (which is only a name to me) and Ripert. Or, in Quebec, Mr. Justice Mignault, not as a justice of the Supreme Court of Canada but as the commentator on Quebec's Code, had-and still has-much more weight than does a judgment on the interpretation of the Code. Now, in our system, the common law system, it is just the reverse. It's interesting to think about the origin of the common law system. We had to have two elements. We had to have judges who wanted to follow what was done before and we had to have what was done before in available written form. That is where the reporters came in. I'm not talking about the reporters tonight. I did that once to the Law Review staff, and it's a fascinating story. We could not have the common law system without reporters. So, as our system grew up, a judge was guided by what had been decided before and not by what some writer said.

If you look at books on jurisprudence, you will find a heading "Sources of the Law". The decisions of judges are a direct source and the writings of scholars are called indirect sources. Blackstone pointed out that there were several writers (I won't name all that Blackstone named but I'll mention the main ones) whose works were accepted as expressing the common law or the law that preceded it. The first one was Glanville in Henry II's time and the next one was Bracton in Henry III's time, and there were a few more like Britton and Fleta but nobody knows who they were. Then you get up to Littleton, and Coke's Commentary on Littleton, and Coke's three other volumes that he called Institutes. And I'd like to tell you a little event that occurred in connection with Coke on Littleton. For awhile after the War we did not have the funds for a library that we have now. I'm proud of our library; we have a wonderful collection and we have wonderful people helping us, and I don't think we know how fortunate we are unless we go to some other law libraries. But in the early years after the War we did not have textbooks, so when a friend of mine from the government phoned over and said, "We're throwing out some second-last editions; will you come over and pick them up?", I was there immediately. There was a second-last edition of Maxwell on Statutes, and of Charlesworth on Negligence. I took them and they were put in our library. We were glad to have them. Well, one of the volumes was Coke on Littleton; it was 1832, a fairly modern edition. So I said to my friend, "Now, look, you really don't want to give that away, do you?" and he said, "Yes, I do". So he knew what he was doing when he gave me Coke

35. D. Sanders, "The Hutterites: A Case Study in Minority Rights" (1964) 42 Can. Bar Rev. 225. 
on Littleton. For the next ten years or so, I kept it in my office along with an edition of Blackstone from the 18th century where the $s$ 's look like $f s$. Lovely it is. And I used to take that Blackstone in with me when we were reading about the rights of ownership in animals, domestic and wild. Blackstone's passage ${ }^{36}$ is simply beautiful and I used to read it to every class. Now, I know those books are in the rare book room and I won't make any cheap joke about having to beat down the door to get the book that I got for the library, because the library staff is very cooperative.

So Blackstone named the four writers I have mentioned: Glanville, Bracton, Littleton and Coke. And, of course, he didn't mention himself. Now, if you read modern books on the question of what works could be mentioned in a court of law as indicating the common law of England, Pollock in 1896 said, "They are called works of authority and they end in 1762 with Foster's Crown Law."37 That excludes Blackstone.

Now, it's interesting to note the position in more modern times. In 1935 the House of Lords decided Woolmington's case ${ }^{38}$ on the burden of proof when the accused pleads the defence of accident. You will remember Viscount Sankey's famous passage: throughout the web of the English Criminal Law, one golden thread is always to be seen-the presumption of innocence. ${ }^{39}$ In holding that the accused did not have to prove the shooting was accidental, Viscount Sankey had to reject a statement in Foster's Crown Law, which was a book of authority. On the other hand, in the very same year there was a case in which a convicted person applied to quash an order binding him over to keep the peace, on the ground that there was no jurisdiction to bind him over because his offence had not threatened violence to anyone else. ${ }^{40}$ (He had warned bookmakers that the police were coming and had previously been convicted eight times of similar offences.) In rejecting the argument, $\mathrm{Mr}$. Justice Humphreys quoted a passage from Blackstone for the proposition that a magistrate can bind over a person whenever it is likely he will break the law even though no breach of the peace is threatened. And His Lordship added, "That in my judgment is the law, and it is too late, in 1935, to attempt to show that Blackstone was wrong."41 Now, I mention those two cases because Foster was rejected by the House of Lords in the same year that the Court of King's Bench accepted Blackstone though Pollock had said that Foster is a work of authority and Blackstone is not.

Then, as time moved on, the rule was relaxed. It is stated in different ways but generally it went this way until the present century: some judges would say, "You can't quote anybody before us unless he's dead", and others say, "You can't quote anybody before us unless he's both dead and was a judge". I cannot detect which was the right rule. We know that Lord Justice Fry wrote Specific Performance, and Lord Lindley wrote both Partnership and Companies. They were certainly quotable after they were dead.

Now, there was a well known little "incident", I suppose I should call it, in the same era, '35 or '36, when Lord Wright had to deal with a case

36. 2 Bl. Comm., c. XXV at 391,392 .

37. Pollock's exact words appear in Pollock, A First Book of Jurisprudence (1896) at 236.

38. Woolmington v. D.P.P. [1935] A.C. 462 (H.L.).

39. Id. at 481 .

40. $R$. v. Sandbach [1935] 2 K.B. 192.

41. Id. at 197 . 
where a man who had a fishery in a stream complained that a sugar beet factory polluted the stream. ${ }^{42}$ The important legal question was whether the plaintiff's right of action was complete on a showing of interference with his right of fishery or whether he also had to prove pecuniary loss. The court quoted a passage from Sir Frederick Pollock's Torts and applied it. In introducing the passage from Pollock, Lord Wright said, "The matter is clearly stated in the work, fortunately not a work of authority, but to which we are all as lawyers indebted ..."43 He was saying in a subtle way that he was glad that Pollock was still alive. However, in the Law Times Reports the editor thought that "fortunately" was a slip for "unfortunately", and so "unfortunately" appears in the Law Times Reports. ${ }^{44}$ I might add that I did not discover this. It is mentioned in every book which deals with works of authority.

In that same era there was a great relaxation in the rule as to whom you could cite. Originally they had to be in this narrow category of works of authority; then any deceased judge; the notable breakthrough came (again in 1935) in Haynes v. Harwood, 45 the rescue case, when the Court of Appeal cited Goodhart's article ${ }^{46}$ and applied it. Goodhart lived for many years after that and so that was quite a breakthrough. Another strong influence in favour of breaking down the old rule came from Lord Denning in his review of the third edition of Winfield. He welcomed the writings of academic lawyers and added that the old idea that their works are not of authority until they have died has long been exploded. ${ }^{47}$ In an address before the Society of Public Teachers of Law, he made the same point.48 So even in England the old rule has largely broken down.

There was another custom that I was brought up on. It is that you do not cite Halsbury. We had a very learned judge here, the Honourable Frank Ford, and he would not accept a citation from Halsbury because it wasn't authentic. Well, you see it every day now. Of course, the passage is just as good as the authority behind it. I don't think I rebel against citing Halsbury now, but I am quite sure my memory is correct: Mr. Justice Ford wouldn't permit it. Now, I don't want to deter those of you having moots who want to cite Halsbury. It can be very useful.

In Australia on the High Court there were judges like Chief Justice Dixon, Mr. Justice Evatt, and Sir Victor Windeyer. They quoted current articles all the time, including those in the Canadian Bar Review. And down in the States, I read somewhere that Holmes once said to Pollock that in Massachusetts the rule used to be strict like the English rule, but that isn't so now. You can pick up any judgment, certainly in the Supreme Court of the United States and find that the judges cite, for example, Professor Paul Freund, who is one of the most learned men there is and he is still alive. They are certainly not bothered by this now and they cite law reviews as well as texts all the time.

Now I come to the position in Canada. This may be well known, Mr. Chairman, but I want to tell it anyway. In 1950, some discontented

42. Nicholls v. Ely Beet Sugar Factory [1936] Ch. 343.

43. Id. at 349.

44. (1936) 154 L.T.R. 531 at 533.

45. [1935] 1 K.B. 146.

46. A. L. Goodhart, "Rescue and Voluntary Assumption of Risk" (1934) 5 Camb. L.J. 192, cited id. at 156.

47. (1947) 63 L.Q.R. 516.

48. The Universities and Law Reform (1949), J.S.P.T.L. 258 at 263. 
landlords were unhappy that the wartime control over the amount of rents was still in effect under the National Emergency Transitional Powers Act, ${ }^{49}$ so they argued that these regulations were invalid because the war power was gone. In fact, this was a very important subject in the civil liberties section of the Canadian Bar Association at that time. At one meeting, my old friend, Jim Milner, who died in 1969, said to me, "Where are you going to go?" I said, "I'm going to the civil liberties section". He said, "Oh, do you want to hear Willes Chitty and his Landlord Protective Association?". At that time they were more concerned about rent controls than they were about freedom of speech.

The case went before the Supreme Court of Canada ${ }^{30}$ and one of the lawyers (I think he must have been supporting the regulations) wanted to cite Vincent MacDonald, who had been Dean of Law at Dalhousie, then became a judge, and was one of our greatest writers in the mid-30's on constitutional matters. He was much like the present Chief Justice of Canada, and felt that Dominion powers had been whittled down by Privy Council rulings. So this counsel wanted to refer to Vincent MacDonald's article in the Canadian Bar Review. 51 You cannot find any reference to this in the judgments but according to the article which George Nicholls wrote in the Bar Review ${ }^{52}$ (remember, he was the editor), Chief Justice Rinfret made the remark, "The Canadian Bar Review is not an authority in this court". When George learned of this, he wrote a lengthy article showing how wrong Chief Justice Rinfret was. If you read that article you can get the whole story of the use by courts of non-judicial writing. Since then I doubt very much that there's been any recurrence of that attitude, and we all know that some of the judges freely refer to articles-current articles-and we must all be glad that they do.

Now I want to say a little more about George Nicholls. He was editor of the Canadian Bar Review roughly from 1945 to 1957. The first editor had been Charles Morse, followed by Dean Wright. They were great editors and Dean Wright also had a tremendous influence on legal education. Nicholls succeeded Dean Wright and he raised the stature of the Canadian Bar Review to a very high degree, there is no question about it. But as I said earlier, in connection with our student case notes, he was a very exacting editor.

In the case on the validity of the barley regulations that forbade profiteering, ${ }^{53}$ the profiteer won in our courts and the Wheat Board had to go to the Privy Council to get the regulations upheld. Well, one of the lawyers who had won in the Canadian courts was angry over a case note by Professor John Willis ${ }^{54}$ criticizing the judgment of the Supreme Court of Canada. The lawyer also criticized Nicholls for publishing the case note. He said, in effect, "You have no business writing a case note on a case that is still in the courts." Nicholls replied to that in a very robust way and of course he was dead right; there is no tradition that you cannot

49. S.C. 1945 , c. 25.

50. Reference re Validity of the Wartime Leasehold Regulations [1950] S.C.R. 124.

51. V. C. MacDonald, "Constitutional Interpretation and Extrinsic Evidence" (1939) 17 Can. Bar Rev. 77.

52. G. V. V. Nicholls, "Legal Periodicals and the Supreme Court of Canada" (1950) 28 Can. Bar Rev. 422.

53. A.-G. Can. v. Hallet \& Carey [1952] A.C. 427, reug. (sub. nom. Canadian Wheat Board v. Nolan) [1951] S.C.R. 81, affg. (1949) 57 Man. L.R. 1 (Man. C.A.).

54. J. Willis, "Administrative Law-Statute Interpretation-Real Constitution versus Lawyer's Constitution" (1951) 29 Can. Bar Rev. 296. 
make a comment on a pending case. If that were so, we couldn't make some flattering remarks about some of the judgments of judges in this room. All of this appears in the Canadian Bar Review of $1951 .^{55}$

Mr. Chairman, I. have one other comment about George Nicholls. To show what integrity and maybe stubbornness he had, as years went on, he was so concerned about the calibre of material in the Canadian Bar Review that this occurred. Now, I am going on my memory here because I was at these meetings. Though I have not documented it, I think you could from the proceedings of the Canadian Bar Association. One year in the early 50's the Right Honourable Arthur Meighen went to Vancouver and talked to the Bar. He was a man of great stature in political life, whatever one felt about his political views. He gave a talk to the Vancouver Bar; I think it was probably that we had too much government and should get back to private enterprise. They sent this speech of Meighen's to George Nicholls and said, "You have to publish it", and Nicholls' position was, "It's got nothing to do with law. I won't publish it". So there was a great furore over that.

And then, a little while later (and this came close to his resignation), I think he turned down at least one or maybe two presidential addresses of the president of the Canadian Bar Association (which paid his salary) and they couldn't understand this. He stuck to his guns and did retire half under fire in 1957.56 There was another factor. There was an element, I don't think it was a large element, but it was certainly vocal, that the Canadian Bar Review was too erudite and what we needed was a chatty, folksy sort of publication and I think the American Bar Association Journal was cited. And I remember one of the proponents of this (and fairly highly placed, too) at a meeting I was at who made an attack on the Canadian Bar Review as being far too abstract. He said, "When it comes, I fire it in the wastepaper basket". Now he made this remark about two months after my article on Chief Justice Harvey had appeared. ${ }^{57}$ You can imagine how I felt.

\section{CONCLUSION}

Now, Mr. Chairman, I just want to make a few comments in conclusion. I tried to think whether I would have any advice to student editors of a law journal and I don't. I met a few in a couple of other law schools I had contact with, and they were the cream of the cream. Maybe it is well known here, and I hesitate to mention this, but down in places like Yale and Harvard when the big New York firms send their hiring partner up to pick the students their letter invariably says, "Law Review or equivalent". Well, the "equivalent" opens it up a bit, but that is the standard they go by. Now my only hesitation in mentioning it is that I would not want to hint that anybody in this law school ever joined the staff of the Law Review so that he could get better articles. I would think he would have a better motive than that, but that is simply the case down

55. See "Correspondence" (1951) 29 Can. Bar Rev. 572 at 573, 578, 580 and 708.

56. See Proceedings, C.B.A. (1957) at 59-76.

57. W. F. Bowker, "The Honourable Horace Harvey: Chief Justice of Alberta” (1954) 32 Can. Bar Rev. 933, 1118. 
there. So I have no comment to editors. There have been a couple of instances where the editor of our Review brought a manuscript to me and my feeling was, "Oh, I think you could let it pass". But he turned it down, and I think he was right because it was nothing new, it was perfunctory. I think his standards were higher than mine and I was rather proud of him.

Now I will close, Mr. Chairman, with a couple of observations I have (I won't call it advice) for people who want to write. The first thing I would say is that many of us have gone through life wishing we had written more. Many of us feel we have a valid criticism of a judgment and yet we let it pass. I wish we could just overcome that hesitance or procrastination and write more. Now I know if I were a judge I would probably feel like Vice-Chancellor Megarry when he referred to a method of teaching law "which treated decisions at first instance as barely worthy of consideration, those of the Court of Appeal as usually wrong, and those of the House of Lords as right, though for the wrong reasons". 58 This was before he was a judge. Of course, he is a great author in his own right.

I think that if a person feels strongly enough about a point he should make it. It doesn't have to be an intemperate criticism of the judges. I have an attitude, and this cannot be generalized, that very often we speak in a strident voice. Now Dean Wright liked to do it, he could excoriate the courts of Ontario and I would say he was dead right every time. However, you can still talk to elderly people connected with law in Ontario who don't smile when you mention Dean Wright's name. He made a great contribution with his writing; but we cannot all adopt what I call "the damn fool" school of writing, and I think that for most of us understatement is a little bit better. I think we do miss a great many opportunities to express ourselves in a temperate way and in a way that would be constructive.

On style, I would be the last one to talk about style. I have told you what George Nicholls did to some of my manuscripts and I sometimes think that many of us who have written opinions and drawn conveyances are probably like John Austin. I am speaking of the author of Jurisprudence. In writing to his future wife he said that his experience in drafting led to such a taste "for perspicuity and precision, that I shall hardly venture on sending a letter of much purpose, even to you, unless it be laboured with the accuracy and circumspection which are requisite in a deed of conveyance". 59 Well, I am sure I have fallen into that category. Frank Scott told me more than once, "Make it live". He didn't say jazz it up a bit but that is what he meant. Of course, it would be wonderful if we all had the style of Frank Scott or Alex Smith (and anyone who has not read Dr. Smith's book on the commerce power in Canada and the United States, or any of his other writings, should do it for that cause alone); but we are not all gifted that way and we just have to put up with it. My last observation would be this: although we may not all have fine writing styles, we don't want our writing to be drab. Holdsworth was drab and so are a lot of other scholars.

A final comment-we often tend to be too prolix. There is a homely phrase, "You can squeeze a lot of water out of most of these articles", and 
I think that is so. An English writer or scholar, I don't know who he was, in the period after the War when the paper shortage was still acute in England and the Law Quarterly had shrunk to practically nothing, looking at the proliferation, the flood of articles from the United States (articles of up to 100 pages and nothing less than a 15 page case note, where the Law Quarterly had about a page), said, "What American legal writing needs most is a paper shortage". Now, maybe, Mr. Chairman, after my comments you might think I need a paper shortage too, but in any event, I am finished. 